\title{
TAXONOMIC ANALYSIS OF VOIVODSHIPS DEVELOPMENT IN TERMS OF ICT USAGE IN ENTERPRISES
}

Paweł Kaczmarczyk, Ph.D.

The State University of Applied Sciences in Płock

Faculty of Economics and Information Technology

Department of Economics

Gałczyńskiego 28, 09-400 Płock, Poland

e-mail:p.kaczmarczyk@pwszplock.pl

Received 31 May 2017, Accepted 2 November 2017

\begin{abstract}
The aim of this paper is to analyse the development of voivodships in terms of ICT usage in enterprises by means of taxonomic methods. The theoretical part of the paper has been devoted to the role of modern information and communication technologies in post-industrial enterprises, in particular to the meaning of these technologies for new management concepts (e-business, online marketing, CRM, network management, $\mathrm{X}$-engineering). The research methodology has been carried out, with special attention being paid to the agglomerative clustering method and optimization clustering method.

The empirical part of the paper presents a taxonomic analysis of voivodships with respect to the employment of ICT in enterprises. Data from the years 2014-2015, published by the Central Statistical Office of Poland, have been used. Seventeen potential diagnostic variables have been identified. In the end, variables with the highest discriminative possibilities were selected. The rankings of the voivodships were thus created. Then, voivodships were clustered by means of Ward's method and the $k$-means method. The obtained results were evaluated regarding their conformity.
\end{abstract}

Keywords: ICT, new management concepts, voivodships, clustering methods

JEL classification: $\mathrm{C} 38, \mathrm{C} 43, \mathrm{O} 33$ 


\section{Introduction}

Due to the fact that since the turn of the $20^{\text {th }}$ and $21^{\text {st }}$ centuries, economic reality is described as the post-industrial economy, enterprises operating in it are described as post-industrial as well. Among the specific characteristics of post-industrial enterprises are: 1) functioning appropriate to the conditions of the service sector, 2) using information and communication technologies for the needs of management and the organization of their activities, 3 ) treatment of intellectual capital as the basis for their development, 4) employment of new management concepts and methods (Gonciarski, 2009, pp. 25-41).

Therefore, information and communication technologies are extremely important for postindustrial enterprises. For example, access to the Internet clearly increases the competitiveness of enterprises (Paszta, 2010, pp. 362-369). A significant link between expenditure on ICT and increase in productivity has also been found (Picot, Wernick, 2007, pp. 660-674). ICT facilitates functioning on the market, enables using intellectual capital more effectively and as a result implementing modern management concepts.

The aim of this paper is to analyse and asses the level of voivodships development in terms of ICT usage in enterprises. The employment of ICT is understood inter alia as the percentage of enterprises in which: employees use computers, employees use computers with access to the Internet, enterprises in which at least one social media is used or enterprises in which computer networks are used to place or receive orders. The analyses were performed by means of the linear ordering method of objects (voivodships) based on the pattern of development and linear ordering methods non-based on the pattern, as well as the hierarchical clustering method and optimization clustering method. Research results constituted a basis to create rankings and singling out clusters with respect to analysed characteristics and providing knowledge on the potential for the socioeconomic development of particular voivodships.

\section{The role of ICT in post-industrial enterprises - rationale of the research}

At the turn of the $20^{\text {th }}$ and $21^{\text {st }}$ centuries, new information and communication technologies became so common that the existing forms of running business activity were rendered irrelevant and replaced by solutions based on digital technology. It is obvious that in practice we come across various solutions in this area and the equally varied level of usage of these new technologies. There are plenty of enterprises on the market whose functioning is based in full on for example the Internet and networks related to it. It needs to be highlighted that new management concepts, which use digital technology in practice, appeared on the market. 
The concept of e-business is among concepts based on ICT that need to be mentioned. The virtual distribution area brings new possibilities. Enterprises which sell digital products (e.g. software, financial information, selling tickets, counselling) can treat the Internet as a fully functioning, modern distribution channel, namely they offer immediate delivery at a significantly lower cost (Chaffey, 2015, pp. 3-40; Chen, 2005, pp. 16-18).

When it comes to the concept of online marketing, the same functions as in its traditional equivalent are distinguished. However, they are carried out by means of the Internet, so in a much faster, cheaper and more effective manner. What is more, online marketing enables reaching a wider public. The effectiveness of this business tool results from the fact that: activity on social media is a new method of coming into contact with the market, it builds trust, enables undertaking dialogue with current and potential customers, provides quick access to up-to-date information on an enterprise or a particular issue, allows collecting data and carrying out market research (Reed, 2012, pp. 3-26; Strauss, Frost, 2009, pp. 28).

Customer Relationship Management is a new management system, the idea of which is to build a stable relationship between an enterprise and its customer that is built on partnership. This relationship is created by placing customers' expectations in the focus of the enterprise and all of its employees. The development of information and communication technologies, namely the development of the Internet, databases, automation of the sales process and integrated IT systems makes the management of contacts with clients and employment on gathered market information faster and more effective. Thus, ICT is an extremely important element in the CRM concept. The advantages of using ICT include: the fact that they enable closer and more individual cooperation with customers in order to create added value for them (working in real time in the whole customer care system is especially important), reduction of management costs of information and customer contacts, supporting decision making processes and the improvement of information flow inside the enterprise, automatization and unification of the customer care process (Chaffey, 2015, pp. 387-465).

Network management employs IT technology to blur the boundaries between organizations and develop fluid relations between an enterprise and customers and suppliers based on partnership. The growing popularity of networking structures results from the fact that they enable to: reduce the feeling of uncertainty, increase the degree of flexibility, ensure adequate capacity and more rapid action to utilize opportunities and chances that the market offers, and increase access to resources and information (Child, Faulkner, Tallman, 2005, pp. 147-148). 
The concept of X-engineering consists in crossing borders between organizations by means of IT. X-engineering is a management concept in which IT and computer numerical control technology are used to enable economic processes to connect some businesses with others as well as enterprises with their customers to obtain rapid progress in productivity and create a new value for persons engaged in these processes (Champy, 2002, pp. 1-17).

The issue of ICT is related to the concept of intellectual capital. Intellectual capital consists of human, structural and relational capital. ICT is part of the structural capital (Cabezas, 2011, pp. 20-24). Raising the competitiveness of an enterprise requires comprehensive measures related to the development of human capital.

Development of intellectual capital and looking for sources of competitive advantage of an enterprise in it is one of the objectives of knowledge management. Knowledge management is rather commonly acknowledged as the most modern and comprehensive management concept. Knowledge management in an organization is managing processes of discovery, creation, acquisition, evaluation and the employment of knowledge to ensure the increase of the intellectual capital and to increase the effectiveness of an organization. As is natural, computer hardware and software is indispensable in the processes of knowledge management. However, even the best databases, despite being a part of sets of knowledge themselves, they do not create values. Obtaining a competitive advantage thanks to them is possible only if they are used by competent employees, who can transform data into information and information into knowledge.

\section{The research method}

Both methods which are non-based on the pattern of development and method based on the pattern for determining aggregated measure (composite measure) have been used in the performed research (Walesiak, 2004a, pp. 351-368; Panek, Zwierzchowski, 2013, pp. 57-97). Both types of methods were used to create a wider basis for the formulation of conclusions. In case of methods which are non-based on the pattern, aggregated measures are calculated by means of functions of converted features of the initial set. Therefore, the arithmetic mean of unitarized data $s_{i}$ and the arithmetic mean of standardized data $h_{i}$ have been calculated. When it comes to the method based on the pattern, Hellwig's method has been used (Hellwig, 1968, pp. 307-327). The aggregated measure $d_{i}$ was determined on the basis of a standardized data matrix. 
The coordinates of the pattern (ideal) object are determined as follows:

$$
x_{0 k}=\left\{\begin{array}{ll}
\max _{i} x_{i j} & j \in S \\
\min _{i} x_{i j} & j \notin S
\end{array},\right.
$$

where $S$ - set of a standardized stimulants.

All variables were stimulants in the research study, so the coordinates of the pattern object were determined on the basis of the first variant.

The $d_{i}$ measure is determined in the following manner:

$$
d_{i}=1-\frac{d_{i 0}}{d_{0}}, \quad i=1,2, \ldots, n,
$$

where:

$$
\begin{gathered}
d_{i 0}=d\left(x_{i}, x_{0}\right)=\sqrt{\sum_{j=1}^{p}\left(x_{i j}-x_{0 j}\right)^{2}}, \\
d_{0}=\bar{d}_{0}+2 s_{d} .
\end{gathered}
$$

Value of $\bar{d}_{0}$ is calculated as the arithmetic mean of $d_{i 0}$ and $s_{d}$ is determined as standard deviation of $d_{i 0}$.

The $d_{i}$ measure is so constructed that the closer to unity is its value, the lower is the distance between the $i$-th object and a pattern object. In this approach, the pattern of development is also called the upper pole of the set of objects. Similarly, an anti-pattern object (lower pole of development) can be determined.

As far as clustering methods are concerned, the agglomerative clustering method and the optimization clustering method were used (Walesiak, 2004b, pp. 316-350; Everitt, Landau, Lesse, Stahl, 2001, pp. 71-142; Milligan, 1996, pp. 341-375; Kopczewska, Kopczewski, Wójcik, 2015, pp. 423-452).

The obvious advantages of agglomerative clustering methods are:

a) the fact that they follow the same procedure (which is called the central agglomerative procedure);

b) the clustering results are presented in the form of a sequence of clustering (therefore, there is a possibility to control the clustering process);

c) the clustering results can be presented graphically in the form of a dendrogram (a tree diagram) which illustrates the order in which clusters are arranged. The obtained hierarchy enables to precisely determine how particular clusters and objects included in them are arranged with respect to each other. 
The algorithm adopted for the agglomerative methods was used:

1. In the distance matrix we look for pairs of clusters $\left(P_{i}\right.$ and $\left.P_{k}\right)$ which are as similar as possible to each other (or closest to each other).

2. The number of clusters is reduced by one, joining two clusters $\left(P_{i}\right.$ and $\left.P_{k}\right)$ into a new cluster.

The distance between the joined clusters $P_{i} \cup P_{k}$ and other clusters are calculated.

Steps 1-3 are repeated until all objects are found in the same cluster.

The distance between the joined clusters $P_{i} \cup P_{k}$ and another $P_{l}$ cluster is defined as follows:

$$
\begin{gathered}
d\left(P_{i} \cup P_{k}, P_{l}\right)=\alpha_{i} d\left(P_{i}, P_{l}\right)+\alpha_{k} d\left(P_{k}, P_{l}\right)+\beta d\left(P_{i}, P_{k}\right)+\gamma\left|d\left(P_{i}, P_{l}\right)-d\left(P_{k}, P_{l}\right)\right|+ \\
+\delta_{i} h\left(P_{i}\right)+\delta_{k} h\left(P_{k}\right)+\varepsilon h\left(P_{l}\right),
\end{gathered}
$$

where:

$\alpha_{i}, \alpha_{k}, \beta, \gamma, \delta_{i}, \delta_{k}, \varepsilon-$ parameters whose values depend on the variant of the agglomerative method,

$h\left(P_{l}\right)$ - degree of incorporation of $P_{l}$ cluster.

Among the agglomerative hierarchical methods, Ward's method was used by means of the squared Euclidean metric (Ward, 1963, pp. 236-244). From the point of view of the correctness of discovery of given types of data structure, Ward's method (in addition to the flexible method) is the best agglomerative hierarchical method. In the case of Ward's method, the values of parameters of the $d\left(P_{i} \cup P_{k}, P_{l}\right)$ formula are as follows:

$$
\alpha_{i}=\frac{w_{i}+w_{l}}{w_{+}}, \quad \beta=\frac{w_{i}+w_{l}}{w_{+}}, \quad \gamma=0, \quad \delta_{i}=0, \quad \varepsilon=0,
$$

where $w_{+}=w_{i}+w_{k}+w_{l} ; w-$ the number of objects in a particular cluster.

In the applied Ward's method, distances between objects were determined by means of the square of Euclidean distance. The square of Euclidean distance between points $x$ and $w$ in $p$-dimensional space is determined in the following manner:

$$
d_{E}^{2}=\sum_{k=1}^{p}\left(x_{k}-w_{k}\right)^{2} .
$$

On this basis, this method has a geometric interpretation. Interpretation of the inter-cluster distance in Ward's method is defined as the growth in the value of the sum squares of distances as a result of joining clusters $P_{i}$ and $P_{k}$ together. 
Optimization algorithms are iterative and based on the assumption that the initial partition of a set of $n$ objects into $u$ clusters is known. The role of these methods is to correct (from the perspective of the defined objective function) the initial partition of a set of objects. The optimization method that was used is the $k$-means method (Sebestyen, 1962; McQueen, 1967, pp. 257-272). This method assumes that each cluster is represented as its geometric centre (centroid) and looks for such a partition of a set of the $n$ object into $u$ clusters for which the value of the objective function is minimum. The objective function employed in the research is as follows:

$$
J=\sum_{j=1}^{k} \sum_{i=1}^{n}\left\|x_{i}^{(j)}-c_{j}\right\|^{2},
$$

where $\|$ is the selected distance measure between observation $x$ and the cluster mean to which it is assigned.

When using the $k$-means method, the algorithm adopted in this method was followed:

1. The starting point is the partition of the set of objects into $s$ clusters, obtained e.g. by means of any clustering method or done randomly. For each cluster of the initial partition, geometric centres and distance between each object and the geometric centre of these clusters are calculated.

2. Assignment of objects to clusters of the closest geometric centre is changed.

3. New geometric centres for each cluster are calculated.

4. Steps 2 and 3 are repeated until the value of the objective function (which presents the quality of clustering) shows changes.

The research results, which have been obtained with the use of the agglomerative clustering method (Ward's method) and the optimization clustering method ( $k$-means method), were compared and evaluated regarding their conformity.

\section{Research results}

The research was conducted on the basis of data from the years 2014-2015. The ordered elements were voivodships $O_{i}(i=1,2, \ldots, 16)$. Diagnostic variables $X_{j}$, describing the ordered elements, were relative frequencies (empirical probabilities) related to enterprises or workers using a particular type of ICT $(j=1,2, \ldots, 17)$. The pre-selected diagnostic variables have been juxtaposed in Table 1 . 
Table 1. Detailed list of pre-selected diagnostic variables

\begin{tabular}{|c|l|}
\hline $\begin{array}{c}\text { Variable } \\
\text { marking }\end{array}$ & \multicolumn{1}{|l|}{ Variable name } \\
\hline $\mathrm{X}_{1}$ & Enterprises using computers \\
\hline $\mathrm{X}_{2}$ & Enterprises with access to the Internet \\
\hline $\mathrm{X}_{3}$ & Enterprises with broadband access to the Internet \\
\hline $\mathrm{X}_{4}$ & $\begin{array}{l}\text { Enterprises with broadband access to the Internet using a DSL connection or other fixed broadband } \\
\text { connection, for example ADSL, SDSL, VDSL, a fibre-optic network, a cable television network }\end{array}$ \\
\hline $\mathrm{X}_{5}$ & Enterprises with broadband access to the Internet using a computer with a 3G modem \\
\hline $\mathrm{X}_{6}$ & Enterprises with broadband access to the Internet using a telephone with 3G technology, e.g. a smartphone \\
\hline $\mathrm{X}_{7}$ & Employees using computers in enterprises \\
\hline $\mathrm{X}_{8}$ & Employees using computers with access to the Internet \\
\hline $\mathrm{X}_{9}$ & Enterprises using at least one social media \\
\hline $\mathrm{X}_{10}$ & Enterprises using social media \\
\hline $\mathrm{X}_{11}$ & Enterprises having blogs and micro-blogs \\
\hline $\mathrm{X}_{12}$ & Enterprises using portals making it possible to share multimedia \\
\hline $\mathrm{X}_{13}$ & Enterprises using Wiki tools \\
\hline $\mathrm{X}_{14}$ & Enterprises placing orders by means of computer networks \\
\hline $\mathrm{X}_{15}$ & Enterprises receiving orders by means of computer networks \\
\hline $\mathrm{X}_{16}$ & Enterprises using e-administration \\
\hline $\mathrm{X}_{17}$ & Enterprises running big data analyses \\
\hline
\end{tabular}

Source: own coverage on the basis of the Central Statistical Office of Poland (GUS, 2014, pp. 34-93; GUS, 2015, pp. 58-114; GUS, 2016, pp. 35-92).

In order to use the same variables in both examined years, the set of pre-selected diagnostic variables was narrowed down to thirteen variables. Then, the value of the descriptive statistics was calculated, among which the value of the arithmetic mean (AM), standard deviation (SD), coefficient of variation (CV) and coefficient of skewness (CS) to both examined years (Table 2).

Table 2. Value of the descriptive statistics

\begin{tabular}{|c|c|c|c|c|c|c|c|c|}
\hline \multirow{2}{*}{ Variable } & \multicolumn{9}{|c|}{2014} & \multicolumn{4}{c|}{2015} \\
\cline { 2 - 9 } & $\mathrm{AM}$ & $\mathrm{SD}$ & $\mathrm{CV}$ & $\mathrm{CS}$ & $\mathrm{AM}$ & $\mathrm{SD}$ & $\mathrm{CV}$ & $\mathrm{CS}$ \\
\hline $\mathrm{X}_{1}$ & 94.1077 & 1.4431 & 1.53 & -0.0374 & 93.6688 & 1.9754 & 2.11 & -0.2934 \\
\hline $\mathrm{X}_{2}$ & 92.8308 & 1.5569 & 1.68 & -0.0953 & 92.2313 & 2.2768 & 2.47 & -0.7016 \\
\hline $\mathrm{X}_{3}$ & 89.4769 & 2.6074 & 2.91 & -0.0002 & 91.3125 & 3.2473 & 3.56 & -0.8863 \\
\hline $\mathrm{X}_{7}$ & 38.4385 & 6.1526 & 16.01 & 1.9316 & 38.1313 & 6.9060 & 18.11 & 1.5634 \\
\hline $\mathrm{X}_{8}$ & 33.2615 & 5.5553 & 16.70 & 1.6071 & 33.2125 & 6.8601 & 20.66 & 1.8079 \\
\hline $\mathrm{X}_{9}$ & 20.5385 & 3.4301 & 16.70 & 0.8007 & 20.5375 & 3.3508 & 16.32 & 0.5984 \\
\hline $\mathrm{X}_{10}$ & 17.2846 & 3.4455 & 19.93 & 1.1316 & 18.6000 & 3.4215 & 18.40 & 0.5305 \\
\hline $\mathrm{X}_{11}$ & 2.9692 & 1.2566 & 42.32 & -0.3555 & 3.4438 & 1.4656 & 42.56 & 1.3560 \\
\hline $\mathrm{X}_{12}$ & 8.0538 & 1.6465 & 20.44 & 0.0943 & 7.1875 & 1.5671 & 21.80 & 0.7278 \\
\hline $\mathrm{X}_{13}$ & 3.2692 & 0.8625 & 26.38 & -0.5075 & 2.2375 & 0.9722 & 43.45 & 0.9055 \\
\hline $\mathrm{X}_{14}$ & 19.5462 & 3.3378 & 17.08 & 0.2992 & 34.1313 & 3.1400 & 9.20 & 1.2009 \\
\hline $\mathrm{X}_{15}$ & 11.1385 & 2.4127 & 21.66 & -0.5240 & 11.4438 & 2.9875 & 26.11 & 0.3766 \\
\hline $\mathrm{X}_{16}$ & 92.5308 & 1.9354 & 2.09 & -0.5565 & 93.5625 & 1.2463 & 1.33 & -0.8169 \\
\hline
\end{tabular}

Source: own calculation. 
Only six variables turned out to have a higher average value in 2015 than in 2014. Nine variables, on the other hand, demonstrated a higher relative dispersion. Variables, whose value of the coefficient of variation exceeded the assumed threshold of $10 \%$, were used in further research (nine variables). Variable $X_{14}$ was also included in clustering analyses, despite the fact that its coefficient of variation equalled to $9.2 \%$ in 2015 . However, in 2014 this variable demonstrated the statistical significance of variation, held a high substantive value in the examined scope of development and the value of $C V$ in 2015 was not significantly lower than its threshold value.

The value of aggregated variables, which were used to create a ranking in both examined years, were determined by means of the methods that were non-based on the pattern of development and method based on the pattern. All variables were treated as stimulants. To mark voivodships, the ISO 3166-2:PL code, developed by the International Organization for Standardization, was used. The exemplary rankings of voivodships, using the $d_{i}$ measure, are presented in Figure 1.

2014

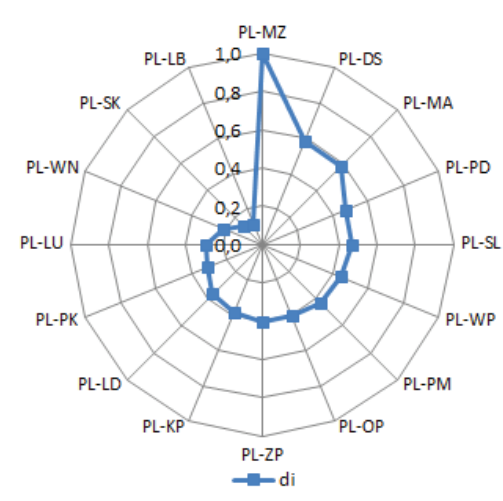

2015

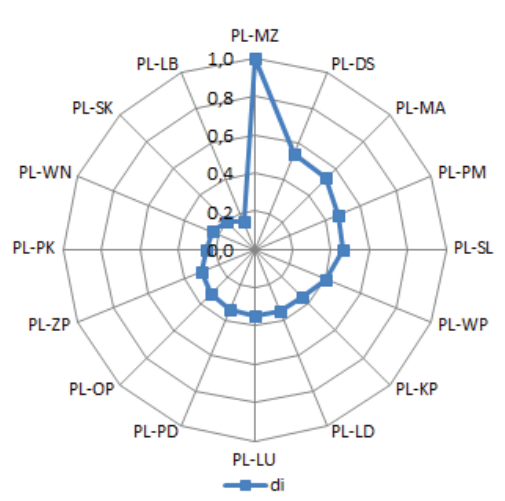

Figure 1. Rankings of voivodships under the measure based on the pattern of development Source: own calculations.

In 2014, in all three rankings (created by means of the $s_{i}, h_{i}, d_{i}$ measures), the three first places were taken by the following voivodships: PL-MZ, PL-DS, PL-MA. The three last places, on the other hand, were usually taken by the following voivodships: PL-WN, PL-SK, PL-LB. In 2015, similar results were obtained, however, when using the $s_{i}, h_{i}$ measures, the second and third places were taken by the following voivodships: PL-MA, PL-DS. In two rankings (in which $s_{i}, d_{i}$ were used), the three last places were taken by the same voivodships, which were listed 
and based on the rankings in 2014. The analysis of the value of Spearman's rank correlation coefficient $\rho$ and Kendall's rank correlation coefficient $\tau$ shows that differences between the rankings of 2014 and 2015 are not significant. In all cases, the values of coefficients turned out to be statistically significant. The lowest values were as follows: $\rho=0.8176$ and $\tau=0.7000$.

The results of clustering the voivodships by means of Ward's method and the square of Euclidean distance for both examined years are presented below (Figure 2).

2014

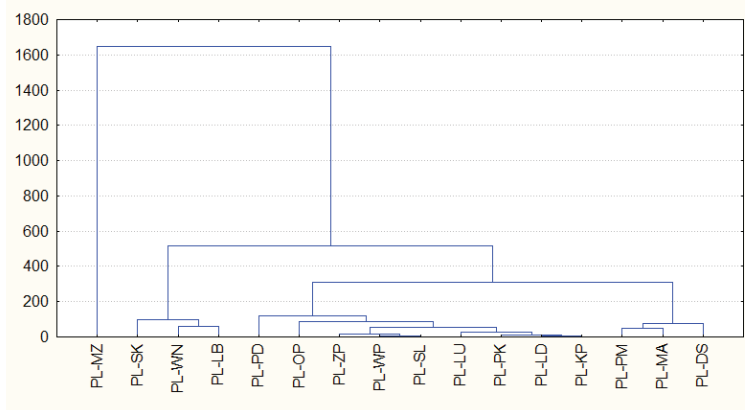

2015

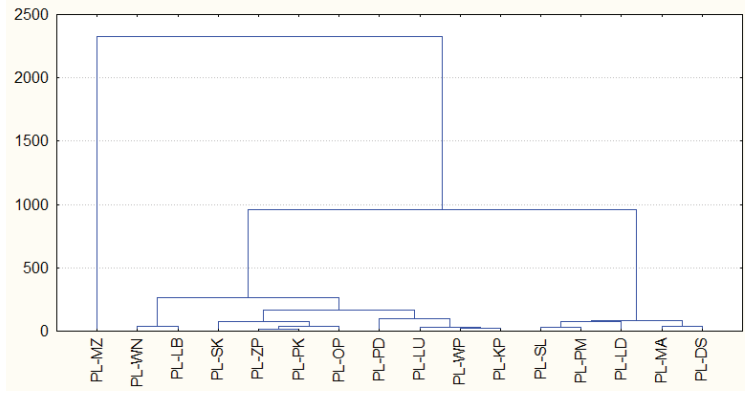

Figure 2. Clustering of voivodships under Ward's method

Source: own calculations.

The analysis of the dendrogram for 2014 shows that four categories of voivodships can be distinguished. The first (the best) category includes only one voivodship, namely: PL-MZ. The second category includes the following voivodships: PL-DS, PL-MA, PL-PM. The third category consists of PL-PD, PL-OP, PL-ZP, PL-WP, PL-SL, PL-LU, PL-PK, PL-LD, PL-KP. Finally, the fourth category (the least developed) includes: PL-WN, PL-SK, PL-LB. In comparison to the previous year, in 2015 the following changes occurred: the second category was extended by the following voivodships: PL-SL and PL-LD (which previously were in the third category) and the PL-SK voivodship went (from the fourth) to the third category. 
The $k$-means method was used to optimize the clustering of voivodships. Four clusters of objects were assumed in the case of both examined years. The clustering obtained in 2014 turned out to be the same as in the case of the agglomerative clustering method. However, in 2015, the partition of voivodships differed only in the case of the PL-SK object belonging (under the optimization method, this object remained in the fourth category). Therefore, the obtained results with the use of Ward's method and the $k$-means method were very similar. The observed changes in structure in the analysed period can therefore be said to be beneficial. The results of the clustering with the use of the $k$-means method are presented in Figure 3.
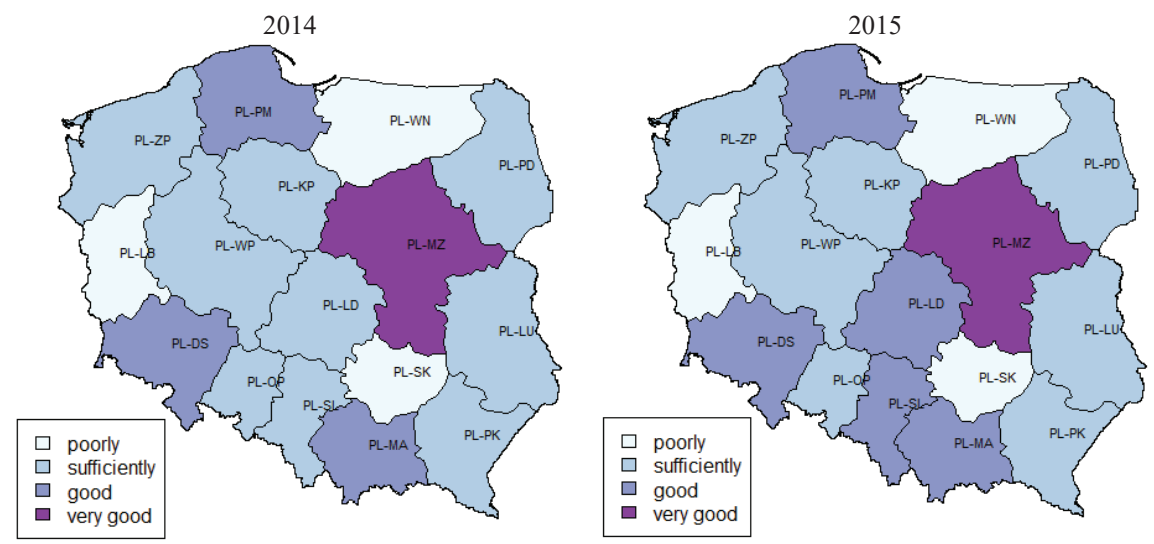

Figure 3. Clustering of voivodships under the $k$-means method

Source: own coverage in $\mathrm{R}$ programme.

Euclidean distances between clusters determined by means of the $k$-means method are presented below (Table 3). Whereas Euclidean distances are found below the main diagonal of the distance matrix for a particular year, squares of the Euclidean distances are found above it.

Table 3. Distances between clusters determined by means of the $k$-means method

\begin{tabular}{|r|r|r|r|r|r|r|r|r|}
\hline \multirow{2}{*}{} & \multicolumn{4}{|c|}{2014} & \multicolumn{4}{c|}{2015} \\
\cline { 2 - 9 } & 1 & 2 & 3 & 4 & 1 & 2 & \multicolumn{1}{c|}{3} & 4 \\
\hline 1 & 0.0000 & 52.6731 & 98.1646 & 156.6697 & 0.0000 & 83.7271 & 151.5079 & 219.7096 \\
\hline 2 & 7.2576 & 0.0000 & 7.6146 & 28.2233 & 9.1503 & 0.0000 & 10.4874 & 34.5028 \\
\hline 3 & 9.9078 & 2.7595 & 0.0000 & 8.4532 & 12.3089 & 3.2384 & 0.0000 & 7.9715 \\
\hline 4 & 12.5168 & 5.3126 & 2.9074 & 0.0000 & 14.8226 & 5.8739 & 2.8234 & 0.0000 \\
\hline
\end{tabular}

Source: own calculations. 
Both the analysis of dendrograms and the values of distances between clusters determined by means of the $k$-means method in 2014 and 2015 shows that in 2015 distances between clusters are higher than in 2014. In this context, the changes of phenomena should be considered as disadvantageous since it proves that the dispersion in respect of the level of development of the analysed phenomenon have increased. Distances between clusters in 2015 were higher because of a higher relative dispersion of diagnostic variables. In the case of the majority of variables ( six of them), the coefficient of variation was higher than in 2014, namely the dispersion of voivodships with respect to the same variable in 2015 was higher than in 2014, whereby the discussed dispersion in the level of variability sometimes were quite high.

\section{Conclusions}

The use of computers in Polish enterprises is very popular, as evidenced by the highest value of mean among the calculated average values of all relative frequencies that were taken into account. However, the average value of the indicator of employment of social media is still at a low level. The use of blogs and microblogs (2014) and Wiki tools (2015) by enterprises was particularly low. Despite an increase in the distance between the clusters of voivodships in terms of the employment of ICT in enterprises in the years of 2014 and 2015, the changes in the analysed period of time should be evaluated positively. In comparison to 2014, in 2015 the number of objects denoted as a second category has increased. What is more, the results of the analysis do not indicate a clear dispersion of the level of the examined phenomenon between eastern and western voivodships.

\section{References}

Cabezas, R. (2011). Opportunities and Diversification Expansion of Business by Analyzing the Structural Capital of Engineering Service Firms. Hamburg: Diplomica Verlag.

Chaffey, D. (2015). Digital Business and E-commerce Management. Strategy, Implementation and Practice. Harlow: Pearson.

Champy, J. (2002). X-Engineering the Corporation: Reinventing Your Business in the Digital Age. New York: Warner Books, Inc.

Chen, S. (2005). Strategic Management of e-Business. West Sussex: John Wiley. 
Child, J., Faulkner, D., Tallman, S. (2005). Cooperative Strategy. Managing Alliances, Networks and Join Venture. Oxford: Oxford University Press.

Everitt, B., Landau, S., Leese, M., Stahl, D. (2011). Cluster Analysis. Chichester: John Wiley and Sons, Ltd.

Gonciarski, W. (2009). Nowoczesne koncepcje i metody zarządzania stosowane w przedsiębiorstwach postindustrialnych. In: K. Piotrowski, M. Świątkowski (eds.), Zarzadzanie w gospodarce postindustrialnej (pp. 25-41). Warszawa: Almamer Wyższa Szkoła Ekonomiczna.

GUS (2014). Społeczeństwo informacyjne w Polsce. Wyniki badań statystycznych z lat 2010 2014. Warszawa.

GUS (2015). Społeczeństwo informacyjne w Polsce. Wyniki badań statystycznych z lat 20112015. Warszawa.

GUS (2016). Społeczeństwo informacyjne w Polsce. Wyniki badań statystycznych z lat 2012 2016. Warszawa.

Hellwig, Z. (1968). Zastosowanie metody taksonomicznej do typologicznego podziału krajów ze względu na poziom ich rozwoju i strukturę wykwalifikowanych kadr. Przegląd Statystyczny, 4, 307-327.

Kopczewska, K., Kopczewski, T., Wójcik, P. (2016). Metody ilościowe w R. Aplikacje ekonomiczne i finansowe. Warsawa: CeDeWu Sp. z o.o.

McQueen, J. (1967). Some Methods for Classification and Analysis of Multivariate Observations. Computer and Chemistry, 4, 257-272.

Milligan, G. (1996). Clustering Validation: Results and Implications for Applied Analyses. In: P. Arabie, L. Hubert, G. de Soete (eds.), Clustering and Classification (pp. 341-375). Singapore: World Scientific.

Panek, T., Zwierzchowski, J. (2013). Statystyczne metody wielowymiarowej analizy porównawczej. Teoria i zastosowania. Warszawa: Szkoła Główna Handlowa.

Paszta, E. (2010). Internet w działalności informacyjnej i komunikacyjnej przedsiębiorstw. In: R. Borowiecki, J. Czekaj (eds.), Zarządzanie zasobami informacyjnymi w warunkach nowej gospodarki (pp. 362-369). Warszawa: Difin.

Picot, A., Wernick, C. (2007). The Role of Government in Broadband Access. Telecommunications Policy. The International Journal on Knowledge Infrastructure Development, Management and Regulation, 31, 660-674.

Reed, J. (2012). Get Up to Speed with Online Marketing. How to Use Websites, Blogs, Social Networking and Much More. New Jersey: Person Education Ltd.

Sebestyen, G.S. (1962). Decision-Making Processes in Pattern Recognition. New York: Macmillan.

Strauss, J., Frost, R. (2009). E-marketing. New Jersey: Prentice Hall. 
Walesiak, M. (2004a). Metody porządkowania liniowego. In: M. Walesiak, E. Gatnar (eds.), Metody statystycznej analizy wielowymiarowej w badaniach marketingowych (pp. 351-368). Wrocław: Wydawnictwo Akademii Ekonomicznej im. Oskara Langego we Wrocławiu.

Walesiak, M. (2004b). Metody klasyfikacji. In: M. Walesiak, E. Gatnar (eds.), Metody statystycznej analizy wielowymiarowej $w$ badaniach marketingowych (pp. 316-350). Wrocław: Wydawnictwo Akademii Ekonomicznej im. Oskara Langego we Wrocławiu.

Ward, J.H. (1963). Hierarchical Grouping to Optimize an Objective Function. Journal of the American Statistical Association, 58, 236-244. 